\title{
ANALISIS EKONOMI PERENCANAAN PEMBANGKIT LISTRIK TENAGA SURYA (PLTS) DI DEPARTEMEN TEKNIK ELEKTRO UNIVERSITAS DIPONEGORO
}

\author{
Fian Hidayat ${ }^{*}$, Bambang Winardi, Agung Nugroho \\ Departemen Teknik Elektro, Universitas Diponegoro \\ J1. Prof. Sudharto, SH, Kampus UNDIP Tembalang, Semarang 50275, Indonesia \\ ${ }^{*}$ Email: fianhidayat9@gmail.com
}

\begin{abstract}
Abstrak
Meningkatnya kebutuhan energi listrik mengakibatkan bertambahnya penggunaan pembangkit listrik berbahan bakar fosil yang ketersediaanya semakin lama semakin menipis. Hal tersebut menjadi alasan berkembangnya energi baru terbarukan. Sel surya merupakan salah satu energi baru terbarukan yang berpotensi untuk dikembangkan di Indonesia, karena intensitas Matahari yang tinggi. Dan diharapkan Pembangkit Listrik Tenaga Surya (PLTS) dapat meringankan beban PLN dalam menyediakan kebutuhan energi listik. Penelitian ini membahas analisa ekonomi perencanaan sistem PLTS terhubung dengan jaringan listrik PLN hasil simulasi HOMER dan PVsyst. Dari sisi ekonomi menganalisis biaya investasi dan alur kas selama investasi PLTS, menggunakan beberapa metode, yaitu Net Present Value (NPV), Benefit-Cost Ratio (B-CR), dan Discounted Payback Period (DPP). Serta menghitung harga jual energi listrik untuk memperoleh kelayakan investasi. Hasil perhitungan analisis ekonomi teknik berdasarkan simulasi HOMER dan PVsyst dengan harga jual energi sebesar RP 840,2 tidak layak, karena tidak mampu mengimbangi biaya investasi awal yang tinggi. Setelah dilakukan analisis sensitivitas dengan menaikan harga jual energi, hasil perhitungan analisis ekonomi teknik berdasarkan simulasi HOMER dapat dikatakan layak apabila harga jual energi sebesar Rp 1932,8/kWh, sedangkan untuk PVsyst sebesar Rp 1440,2/kWh, karena mampu menutup biaya investasi.
\end{abstract}

Kata kunci: HOMER, PVsyst, NPV, B-CR, DPP

\begin{abstract}
The increasing demand for electrical energy has resulted in an increase in the use of fossil-fueled power plants which are increasingly depleted. This is the reason for the development of new renewable energy. Solar cells are one of the new renewable energy that has the potential to be developed in Indonesia, because of the high intensity of the Sun. And it is expected that the Solar Power Plant (PLTS) can ease the burden of PLN in providing electric energy needs. This final project discusses the economic analysis of the PLTS system planning connected with the PLN electricity network simulation results of HOMER and PVsyst. From an economic standpoint analyzing investment costs and cash flow during PLTS investments, using several methods, namely Net Present Value (NPV), Benefit-Cost Ratio (B-CR), and Discounted Payback Period (DPP). As well as calculating the selling price of electrical energy to obtain investment feasibility. The results of the calculation of technical economic analysis based on HOMER and PVsyst simulations with an energy selling price of $\mathrm{Rp} 840.2$ is not feasible, because they are not able to compensate for the high initial investment costs. After sensitivity analysis has been carried out by increasing the selling price of energy, the results of the calculation of the economic analysis technique based on the HOMER simulation can be said to be feasible if the selling price of energy is Rp. 1932,8/kWh, while for PVsyst Rp. Rp 1440,2/kWh because it is able to cover investment costs.
\end{abstract}

Keywords: HOMER, PVsyst, NPV, B-CR, DPP

\section{Pendahuluan}

Energi merupakan salah satu kebutuhan utama dalam kehidupan manusia. Kebutuhan energi yang terus meningkat dapat dijadikan sebagai indikator kemakmuran manusia, namun bersamaan dengan hal itu akan menimbulkan masalah dalam usaha penyediaanya. Sebagian besar manusia masih mengandalkan energi fosil untuk memenuhi kebutuhan energi. Sehingga semakin lama energi fosil yang ada akan semakin menipis. Selama tahun 2010-2015, konsumsi jumlah energi meningkat ratarata $1,3 \%$ per tahun[1]. Konsumsi jumlah energi terus meningkat sejalan dengan meningkatnya pertumbuhan ekonomi penduduk. Dalam Outlook Energi Indonesia 2017, pertumbuhan rata-rata kebutuhan energi diperkirakan akan meningkat dari 3,6\% pada tahun 2015 menjadi menjadi $6,4 \%$ pada tahun 2050[1]. Pada tahun 2015 kapasitas total pembangkit nasional meliputi 
pembangkit dari PLN, Independent Power Producer (IPP) dan Private Power Utility (PPU) di wilayah Indonesia adalah sebesar 53,97 GW. Dimana terdiri dari pembangkit PLN (75 \%), Independent Power Producer (IPP) sebesar (16 \%) dan Private Power Utility (PPU) sebsar (9\%)[2].Kondisi cadangan energi fosil yang terus berkurang seharusnya diantisipasi oleh Pemerintah Indonesia untuk lebih meningkatkan penggunaan energi baru terbarukan (EBT). Indonesia memiliki potensi sumber daya energi baru terbarukan (EBT) yang cukup besar dengan variasi yang cukup beragam. Potensi sumber daya energi terbarukan terbanyak adalah tenaga air disusul Ocean Thermal Energy Conversion (OTEC), tenaga surya dan biomassa[3]. Kurangnya pemanfaatan sel surya sebagai sumber energi listrik di Indonesia sebagai sumber energi listrik di Indonesia terus meningkat. Dengan potensi cahaya matahari yang cukup tinggi di Indonesia diharapkan pemanfaatan sel surya sebagai sumber energi listrik di Indonesia dapat menjadi bagian solusi yang baik untuk masalah ini. Penelitian sebelumnya yang bertujuan untuk untuk pengembangan teknologi yang mampu menyuplai kebutuhan energi dengan menggunakan energi terbarukan dengan judul perencanaan pembangkit listrik hybrid di Pulau Gili Labak Kabupaten Sumenep Madura menggunakan teknik distributed generation [4], membahas tentang studi beban listrik di Pulau Gili Labak, studi potensi penyinaran matahari sebagai sumber energi terbarukan, analisis sistem, dan kemudian mendesain sistem. Penelitian yang lain yg dilakukan oleh Kunaifi pada tahun 2011[5] dengan judul desain pembangkit listrik hybrid (plts/diesel) untuk meningkatkan pelayanan kesehatan di puskesmas Kecamatan Gema Kabupaten Kampar membahas tentang studi beban listrik di salah satu puskesmas di Kecamatan Gema, studi potensi energi surya di Desa Gema, dan desain sistem. Untuk itu diperlukan upaya-upaya pengembangan teknologi yang mampu menyuplai kebutuhan energi dengan menggunakan energi terbarukan yang ramah lingkungan. Pembangkit Listrik Tenaga Surya (PLTS) merupakan salah satu aplikasi dari penggunaan energi terbarukan, dengan matahari sebagai sumber energi primer.

\section{Metode}

\subsection{Teknik Analisis Ekonomi Kelayakan Investasi}

2.1.1. Net Present Value (NPV) [2][3]

Untuk menghitung Net Present Value (NPV) dipergunakan persamaan sebagai berikut :

$N P V=\sum_{t=1}^{n} \frac{N C F_{t}}{(1-i)^{t}}-I I$

Dimana :

$\mathrm{NCFt}=$ Net Cash Flow periode tahun ke-1 sampai tahun ke-n

II = Investasi awal (Initial Investment)

i $\quad=$ Tingkat diskonto

$\mathrm{n} \quad=$ Periode dalam tahun (umur investasi)
Kriteria pengambilan keputusan apakah usulan investasi layak diterima atau layak ditolak adalah sebagai berikut:

- Jika nilai NPV yang didapatkan adalah positif maka proyek tersebut layak dilaksanakan karena hal itu mengindikasikan bahwa perhitungan investasi proyek itu telah mencapai kondisi yang mampu memberi keuntungan keuntungan sampai periode yang diperhitungkan.

- Jika nilai NPV yang didapatkan adalah negatif maka proyek tersebut tidak layak dilaksanakan karena hal itu mengindikasikan bahwa perhitungan investasi proyek itu belum mencapai kondisi yang mampu memberi keuntungan sampai periode yang diperhitungkan.

\subsubsection{Benefit - Cost Ratio (B-CR)[9]}

Dalam melakukan perhitungan Cost Benefit digunakan rumus perhitungan sebagai berikut:

Benefit Cost Ratio $(B C R)=\frac{B}{C}=\frac{\text { Benefit }}{\text { Cost }}$

Dari persamaan diatas, bisa diketahui nilai Benefit Cost Ratio (BCR). Jika B/C Ratio lebih besar dari 1, maka manfaat (benefit) yang dihasilkan selama umur ekonomis proyek lebih dari biaya (cost) dan investasi (investement), sehingga proyek tersebut baik (favourable). Dan jika B/C Ratio kurang dari 1, maka benefit yang dihsilkan selama umur ekonomis proyek tidak cukup untuk menutupi cost dan investement, sehingga proyek disebut tidak baik (unfavourable).

\subsubsection{Discounted payback period [2][3]}

Payback period adalah periode lamanya waktu yang dibutuhkan untuk mengembalikan nilai investasi melalui penerimaan-penerimaan yang dihasilkan oleh proyek. Discounted payback period (DPP) adalah periode pengembalian uang yang dihitung dengan menggunakan discount factor. DPP dapat dicari dengan menghitung berapa tahun alur kas bersih nilai sekarang kumulatif yang ditaksir akan sama dengan investasi awal.

Kriteria pengambilan keputusan apakah proyek yang ingin dijalankan layak atau tidak layak untuk metode ini adalah:

- Investasi proyek akan dinilai layak apabila DPP memiliki periode waktu lebih pendek dari umur proyek.

- Investasi proyek belum dinilai layak apabil DPP memiliki periode waktu lebih panjang dari umur proyek.

\subsection{Biaya Siklus Hidup (Life Cycle Cost)}

Biaya siklus hidup suatu sistem adalah semua biaya yang dikeluarkan oleh suatu sistem, selama kehidupannya. Biaya siklus hidup (LCC) diperoleh dengan persamaan sebagai berikut : 
$\mathrm{LCC}=\mathrm{C}+\mathrm{M}_{\mathrm{PW}}+\mathrm{R}_{\mathrm{PW}}$

Dimana :

LCC = Biaya siklus hidup (Life Cycle Cost)

$\mathrm{C} \quad=$ Biaya investasi awal adalah biaya awal yang dikeluarkan untuk pembelian komponen-komponen PLTS, biaya instalasi dan biaya lainnya misalnya biaya untuk rak penyangga

MPW = Biaya nilai sekarang untuk total biaya pemeliharaan dan operasional selama $\mathrm{n}$ tahun atau selama umur proyek

RPW = Biaya nilai sekarang untuk biaya penggantian yang harus dikeluarkan selama umur proyek. Contohnya adalah biaya untuk penggantian baterai

Nilai sekarang biaya tahunan yang akan dikeluarkan beberapa waktu mendatang (selama umur proyek) dengan jumlah pengeluaran yang tetap, diperoleh dengan persamaan sebagai berikut :[3][10]

$P=A\left[\frac{(1+i)^{n}-1}{i(1+i)^{n}}\right]$

Dimana :

$\mathrm{P} \quad=$ Nilai sekarang biaya tahunan selama umur proyek

A = Biaya tahunan

i $\quad=$ Tingkat diskonto

$\mathrm{n} \quad=$ Umur proyek

\subsection{Faktor Pemulihan Modal (Capital Recovery Factor)}

Faktor pemulihan modal diperoleh dengan persamaan sebagai berikut[6]:

$\mathrm{CRF}=\frac{i(1+i)^{n}}{(1+i)^{n}-1}$

Dimana :

$\mathrm{CRF}=$ Faktor pemulihan modal

i $\quad=$ Tingkat diskonto

$\mathrm{n} \quad=$ Periode dalam tahun (umur investasi)

\subsection{Biaya energi (Cost of Energy) [3][6]}

Biaya energi (Cost Of Energy) PLTS diperoleh dengan persamaan sebagai berikut [3][7]:

$\mathrm{COE}=\frac{\mathrm{LCC} \times \mathrm{CRF}}{\mathrm{AkWh}}$

Dimana :

$\mathrm{COE}=$ Cost of Energy atau Biaya Energi $(\mathrm{Rp} / \mathrm{kWh})$

$\mathrm{CRF}=$ Faktor pemulihan modal

$\mathrm{AkWh}=$ Energi yang dibangkitkan tahunan (kWh/tahun)

\section{Hasil dan Analisis 3.1. Perancangan Desain PLTS}

Pemasangan instalasi PLTS di sarana parkir sepeda motor Departemen Teknik Elektro Universitas Diponegoro ditempatkan sebagai atap sarana parkir tersebut dengan total luas lahan mencapai 980,0505 m2. Namun berdasarkan bentuk dan demografi sarana parkir sepeda motor Departemen Teknik Elektro Universitas Diponegoro dan spesifikasi modul panel surya, maka pemanfaatan lahan sarana parkir yang dapat digunakan sebagai PLTS hanya sebesar 758,28 m2 dengan jumlah panel surya sebanyak 390 buah panel. Berikut merupakan denah sarana parkir Departemen Teknik Elektro Universitas Diponegoro dan rencana pemasangan panel surya sebagai atapnya:

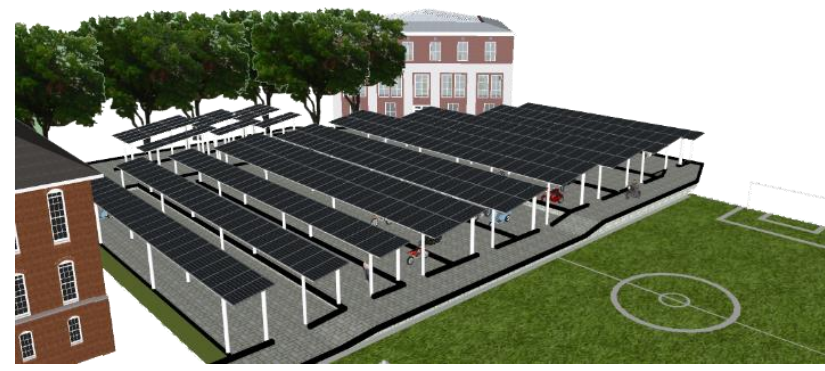

Gambar 1. Visualisasi desain perancangan PLTS di Sarana parkir sepeda motor Departemen Teknik Elektro Universitas Diponegoro

\subsection{Komponen - Komponen Sistem Pembangkit Listrik Tenaga Surya}

\subsubsection{Panel Surya}

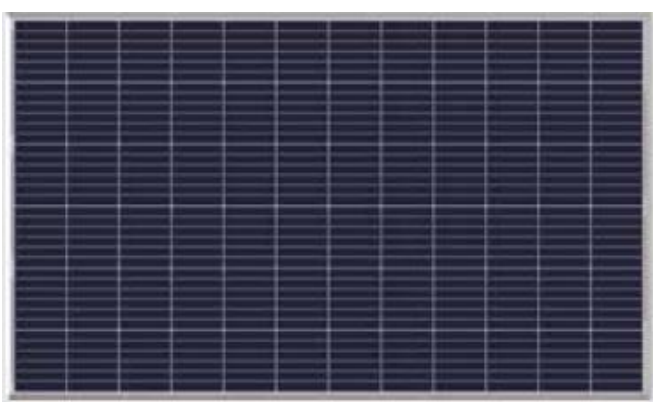

Gambar 2. Panel surya YL320P-35b

Tabel 1. Spesifikasi panel surya YL320P-35b

\begin{tabular}{ll}
\hline \multicolumn{1}{c}{ Variabel } & Nilai \\
\hline Daya Maksimum $\left(P_{\max }\right)$ & $320 \mathrm{Wp}$ \\
Tegangan Rangkaian Terbuka $\left(\mathrm{V}_{\mathrm{oc}}\right)$ & $46,0 \mathrm{~V}$ \\
Arus Hubung Singkat $\left(\mathrm{I}_{\mathrm{sc}}\right)$ & $9,18 \mathrm{~A}$ \\
Tegangan Maksimum $\left(\mathrm{V}_{\mathrm{mp}}\right)$ & $37,0 \mathrm{~V}$ \\
Arus Maksimum $\left(\mathrm{I}_{\mathrm{mp}}\right)$ & $8,64 \mathrm{~A}$ \\
Temperatur Kerja & $-40-85^{\circ} \mathrm{C}$ \\
Efesiensi $\left(\eta_{p v}\right)$ & $16,5 \%$ \\
Daya Maksimum $\left(\mathrm{P}_{\max }\right)$ & $320 \mathrm{Wp}$ \\
\hline
\end{tabular}




\subsubsection{Inverter}

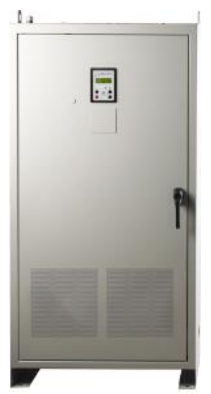

Gambar 3. Inverter Princeton Power System tipe GTIB-100G1.2

Tabel 2. Spesifikasi Inverter Princeton Power System tipe GTIB-100-G1.2

\begin{tabular}{|c|c|}
\hline Variabel & Nilai \\
\hline \multicolumn{2}{|l|}{ Inverter AC Keluaran } \\
\hline Daya Keluaran & $100 \mathrm{~kW}$ \\
\hline Arus Keluaran Maksimum 60 detik (rms) & $142 \mathrm{~A}$ \\
\hline $\begin{array}{l}\text { Tegangan Keluaran } \\
\text { DC Port Battery }\end{array}$ & $380 \mathrm{Vac}+10 \%,-12 \%$ \\
\hline Tegangan DC & $290-800$ VDC \\
\hline Daya Maksimal & $110 \mathrm{Kw}$ \\
\hline Arus DC Maksimal & $380 \mathrm{~A}$ \\
\hline DC PORT PV & \\
\hline PV MPPT & 290-780 VDC \\
\hline $\begin{array}{l}\text { Tegangan Opeb Circuit } \\
\text { AC Input }\end{array}$ & 280-780 VDC \\
\hline Tegangan AC & $380 \mathrm{Vac}+10 \%,-12 \%$ \\
\hline Fekuensi & $50 \mathrm{~Hz}$ \\
\hline Arus AC & 133 A RMS \\
\hline Efesiensi ( $\left.\eta \_l\right)$ & $97 \%$ \\
\hline
\end{tabular}

\subsection{Perhitungan Investasi Sistem PLTS}

Yang termasuk ke dalam biaya investasi awal untuk rancangan sistem PLTS di Departemen Teknik Elektro Universitas Diponegoro adalah: biaya untuk komponen sistem PLTS, biaya pengiriman komponen dan biaya instalasi sistem PLTS. Yang termasuk kedalam komponen biaya sistem PLTS adalah pembelian panel dan inverter. Untuk jenis biaya pemasangan rak panel sudah termasuk untuk biaya instalasi sistem PLTS.

Dari Bab sebelumnya telah dibahas kompenen yang dibutuhakan, antara lain 390 unit panel surya YGE 72 CELL, 2 buah inverter GITB-100-G1.2 dan Generator Set Olympian. Keseluruhan informasi untuk setiap komponen biaya investasi awal sistem PLTS didapatkan dari mencari informasi dari internet dan dengan menanyakan ke penjual. Namun ada sumber/informasi tersebut mencantumkan harga dalam mata uang Dollar (\$), sehingga harus diubah kedalam nilai mata uang Rupiah ( $\mathrm{Rp}$ ) yaitu sebesar $\mathrm{Rp}$ 14.515 per $\$ 1,00$ (Kamis, 26 Juli 2018).

Panel surya membeli di Sentra Energi sekaligus instalasi dan pemasangan, kemudian jasa pengiriman menggunakan jasa PT Transporindo Agung Sejahtera. Untuk inverter membeli di Priceton Power Systems, kemudian jasa pengiriman inverter dari Amerika ke Indonesia menggunakan jasa PT. Arkana Putra Perdanna menggunakan jalur laut dan setelah sampai di Indonesia menggunakan jasa PT Transporindo Agung Sejahtera. Rak Panel surya dibeli lewat Bukalapak dengan pengiriman menggunakan JNE. Untuk Kanopi membeli di CV. Truss Guna Sanjaya yang beralamat di Semarang sehingga untuk biaya pengiriman gratis dan pemasangan juga gratis.

\section{Tabel 3. Perhitungan biaya investasi awal sistem PLTS}

\begin{tabular}{|c|c|c|c|c|c|}
\hline \multirow{2}{*}{$\begin{array}{l}\text { Nama Komponen } \\
\text { Panel Surya YGE } 72 \\
\text { CELL }\end{array}$} & \multirow{2}{*}{$\begin{array}{c}\text { Jumlah } \\
390\end{array}$} & \multicolumn{2}{|c|}{ Harga } & \multicolumn{2}{|c|}{ Total Harga } \\
\hline & & $\mathrm{Rp}$ & 2.599 .000 & $\mathrm{Rp}$ & 1.013 .610 .000 \\
\hline $\begin{array}{l}\text { Biaya Pengiriman } \\
\text { Panel Surya }\end{array}$ & 1 & $\mathrm{Rp}$ & 17.000 .000 & Rp & 17.000 .000 \\
\hline $\begin{array}{l}\text { Pemasangan dan } \\
\text { instalasi }\end{array}$ & 80 & $\mathrm{Rp}$ & 1.500 .000 & Rp & 120.000 .000 \\
\hline Akomodasi & 1 & $\mathrm{Rp}$ & 25.000 .000 & $\mathrm{Rp}$ & 25.000 .000 \\
\hline Rak Sel Surya & 195 & Rp & 450.000 & $\mathrm{Rp}$ & 87.750 .000 \\
\hline $\begin{array}{l}\text { Biaya pengiriman Rak } \\
\text { Sel Surya }\end{array}$ & 195 & $\mathrm{Rp}$ & 36.000 & Rp & 7.020 .000 \\
\hline Kanopi & 759 & $\mathrm{Rp}$ & 117.000 & $\mathrm{Rp}$ & 88.803 .000 \\
\hline $\begin{array}{l}\text { Inverter GITB-100- } \\
\text { G1.2 }\end{array}$ & 2 & $\mathrm{Rp}$ & 66.043 .250 & $\mathrm{Rp}$ & 132.086 .500 \\
\hline $\begin{array}{l}\text { Biaya Pengiriman } \\
\text { Inverter }\end{array}$ & 1 & $\mathrm{Rp}$ & 95.000 .000 & Rp & 95.000 .000 \\
\hline Total Biaya Investasi & & & & Rp & 1.586 .269 .500 \\
\hline
\end{tabular}

\subsection{Pengolahan Data Biaya Sistem PLTS Simulasi HOMER}

Tabel 4. Hasil simulasi homer PV-Grid

\begin{tabular}{lccccc}
\hline & $\begin{array}{c}\text { Energy } \\
\text { Purchased } \\
(\mathrm{kWh})\end{array}$ & $\begin{array}{c}\text { Energy } \\
\text { Sold } \\
(\mathrm{kWh})\end{array}$ & $\begin{array}{c}\text { Net } \\
\text { Purchases } \\
(\mathrm{kWh})\end{array}$ & $\begin{array}{c}\text { Peak } \\
\text { Demand } \\
(\mathrm{kW})\end{array}$ & $\begin{array}{c}\text { Energy } \\
\text { Charge } \\
(\$)\end{array}$ \\
\hline Jan & 16,040 & 4,428 & 11,611 & 114 & 556 \\
Feb & 12,365 & 5,120 & 7,244 & 109 & 330 \\
Mar & 12,369 & 6,439 & 5,931 & 104 & 254 \\
Apr & 13,404 & 5,291 & 8,113 & 110 & 373 \\
May & 13,883 & 5,884 & 7,998 & 114 & 363 \\
Jun & 11,105 & 7,352 & 3,753 & 104 & 137 \\
Jul & 11,584 & 6,834 & 4,751 & 100 & 191 \\
Aug & 12,451 & 6,263 & 6,188 & 100 & 268 \\
Sep & 10,207 & 7,730 & 2,477 & 105 & 70 \\
Oct & 14,429 & 5,397 & 9,032 & 116 & 419 \\
Nov & 15,999 & 4,674 & 11,325 & 123 & 540 \\
Dec & 14,952 & 5,457 & 9,495 & 117 & 442 \\
Annual & 158,788 & 70,870 & 87,918 & 123 & 3,944 \\
\hline
\end{tabular}

Dari hasil simulasi software HOMER maka dapat diketauhi pendapatan yang didapat dari penjualan energi listrik yang disalurkan ke PLN. Hasil perhitungan pendapatan energi listrik yang dapat disalurkan ke sistem jaringan listrik PLN selama 1 tahun dengan harga jual energi yang ditetapkan sebesar Rp 840,2 sesuai dengan Peraturan Menteri ESDM Nomor 50 Tahun 2017[8] 
Tabel 5. Perhitungan pendapatan energi listrik yang disalurkan ke PLN

\begin{tabular}{|c|c|c|}
\hline Bulan & kWh Jual & Pendapatan (Rp) \\
\hline Januari & 4428 & Rp3.720.406 \\
\hline Februari & 5120 & Rp4.301.824 \\
\hline Maret & 6439 & Rp5.410.048 \\
\hline April & 5291 & Rp4.445.498 \\
\hline Mei & 5884 & Rp4.943.737 \\
\hline Juni & 7352 & Rp6.177.150 \\
\hline Juli & 6834 & Rp5.741.927 \\
\hline Agustus & 6263 & Rp5.262.173 \\
\hline September & 7730 & Rp6.494.746 \\
\hline Oktober & 5397 & Rp4.534.559 \\
\hline November & 4674 & Rp3.927.095 \\
\hline Desember & 5457 & Rp4.584.971 \\
\hline Jumlah & 70.870 & Rp59.544.134 \\
\hline
\end{tabular}

Tabel 6. Hasil simulasi homer Grid

\begin{tabular}{cccccc}
\hline Month & $\begin{array}{c}\text { Energy } \\
\text { Purchased } \\
(\mathrm{kWh})\end{array}$ & $\begin{array}{c}\text { Energy } \\
\text { Sold } \\
(\mathrm{kWh})\end{array}$ & $\begin{array}{c}\text { Net } \\
\text { Purchases } \\
(\mathrm{kWh})\end{array}$ & $\begin{array}{c}\text { Peak } \\
\text { Demand } \\
(\mathrm{kW})\end{array}$ & $\begin{array}{c}\text { Energy } \\
\text { Charge } \\
(\$)\end{array}$ \\
\hline Jan & 29,546 & 0 & 29,546 & 128 & 1,497 \\
Feb & 25,731 & 0 & 25,731 & 128 & 1,304 \\
Mar & 28,312 & 0 & 28,312 & 128 & 1,435 \\
Apr & 27,040 & 0 & 27,040 & 128 & 1,370 \\
May & 29,546 & 0 & 29,546 & 128 & 1,497 \\
Jun & 27,040 & 0 & 27,040 & 128 & 1,370 \\
Jul & 28,312 & 0 & 28,312 & 128 & 1,435 \\
Aug & 29,546 & 0 & 29,546 & 128 & 1,497 \\
Sep & 25,806 & 0 & 25,806 & 128 & 1,308 \\
Oct & 29,546 & 0 & 29,546 & 128 & 1,497 \\
Nov & 28,275 & 0 & 28,275 & 128 & 1,433 \\
Dec & 27,078 & 0 & 27,078 & 128 & 1,372 \\
Annual & 335,781 & 0 & 335,781 & 128 & 17,015 \\
\hline
\end{tabular}

Tabel 7. Perhitungan penghematan setelah PLTS terpasang

\begin{tabular}{llll}
\hline Bulan & $\begin{array}{c}\text { Pembayaran } \\
\text { sebelum ada } \\
\text { PLTS }\end{array}$ & $\begin{array}{c}\text { Pembayaran } \\
\text { setelah ada } \\
\text { PLTS }\end{array}$ & $\begin{array}{c}\text { Penghematan } \\
\text { (Rp) }\end{array}$ \\
\hline Januari & Rp21.716.310 & Rp11.789.400 & Rp9.926.910 \\
Februari & Rp18.912.285 & Rp9.088.275 & Rp9.824.010 \\
Maret & Rp20.809.320 & Rp9.091.215 & Rp11.718.105 \\
April & Rp19.874.400 & Rp9.851.940 & Rp10.022.460 \\
Mei & Rp21.716.310 & Rp10.204.005 & Rp11.512.305 \\
Juni & Rp19.874.400 & Rp8.162.175 & Rp11.712.225 \\
Juli & Rp20.809.320 & Rp8.514.240 & Rp12.295.080 \\
Agustus & Rp21.716.310 & Rp9.151.485 & Rp12.564.825 \\
September & Rp18.967.410 & Rp7.502.145 & Rp11.465.265 \\
Oktober & Rp21.716.310 & Rp10.605.315 & Rp11.110.995 \\
November & Rp20.782.125 & Rp11.759.265 & Rp9.022.860 \\
Desember & Rp19.902.330 & Rp10.989.720 & Rp8.912.610 \\
\hline \multicolumn{1}{c}{ Jumlah } & Rp246.796.830 & Rp116.709.180 & Rp130.087.650 \\
\hline
\end{tabular}

Untuk golongan S3 terdapat dua tarif listrik yaitu saat waktu beban puncak dan luar beban puncak. Penetapan harga waktu beban puncak dan luar waktu beban puncak di ambil dari aplikasi PLN mobile, dimana harga waktu beban puncak Rp 1102.5 dan harga luar waktu beban puncak Rp 735. Untuk mempermudah perhitungan digunakan harga Rp 735 karena pada waktu beban puncak jam 18.00-22.00 penggunaan beban di Departemen Teknik Elektro Universitas Diponegoro hanya sebesar 1,48 kWh dimana hanya digunakan untuk penerangan pada malam hari. Jadi dianggap dengan harga Rp 1102,5 pada waktu beban puncak tidak begitu berpengaruh, sehingga harga yang digunakan adalah Rp 735.

\subsubsection{Analisis Ekonomi Kelayakan Investasi simulasi HOMER}

Kelayakan investasi PLTS yang akan dirancang di Departemen Teknik Elektro Universitas Diponegoro ditentukan berdasarkan hasil perhitungan Net Present Value (NPV), Profitability Index (PI) dan Discounted Payback Period (DPP).

Arus kas bersih tahunan PLTS yang akan dirancang di Departemen Teknik Elektro sebesar Rp 116.534.244. Untuk arus kas keluar tahunan PLTS diperhitungkan sebesar Rp 73.097.540. Pendapatan yang diperoleh selama 25 tahun adalah sebesar Rp 968.666.432, masih jauh dari biaya investasi yang sebesar Rp 1.586.269.500. Dan apabila dihitung menggunakan metode Net Present Value (NPV), Benefit-Cost Ratio (B-CR) dan Discounted Payback Period (DPP) maka hasil kelayakan dapat dilihat seberti tabel dibawah :

Tabel 8. Analisis kelayakan investasi PLTS dengan harga jual energi PLN Rp 840,2/kWh

\begin{tabular}{|c|c|c|c|}
\hline $\begin{array}{l}\text { Analisis } \\
\text { Kelayakan }\end{array}$ & $\begin{array}{l}\text { Kriteria } \\
\text { Kelayakan }\end{array}$ & $\begin{array}{l}\text { Hasil } \\
\text { Analisis } \\
\text { Investasi }\end{array}$ & Kesimpulan \\
\hline \multirow{2}{*}{$\begin{array}{l}\text { Net Present Value } \\
\text { (NPV) }\end{array}$} & Layak (NPV > 0) & \multirow{2}{*}{$\begin{array}{l}-\mathrm{Rp} \\
617.603 .068\end{array}$} & \multirow{2}{*}{$\begin{array}{l}\text { Investasi dianggap } \\
\text { tidak layak } \\
\text { diinves-tasikan. }\end{array}$} \\
\hline & $\begin{array}{l}\text { Tidak Layak } \\
(N P V<0)\end{array}$ & & \\
\hline \multirow[t]{2}{*}{$\begin{array}{l}\text { Benefit } \\
\text { Ratio } \\
\text { (B-CR) }\end{array}$} & $\begin{array}{l}\text { Layak }(B-C R> \\
\text { 1) }\end{array}$ & \multirow[t]{2}{*}{0,61} & \multirow{2}{*}{$\begin{array}{l}\text { Investasi dianggap } \\
\text { tidak layak } \\
\text { diinves-tasikan. }\end{array}$} \\
\hline & $\begin{array}{l}\text { Tidak Layak (B- } \\
\text { CR }<1)\end{array}$ & & \\
\hline \multirow[t]{2}{*}{$\begin{array}{l}\text { Discounted } \\
\text { Payback Period } \\
\text { (PP) }\end{array}$} & $\begin{array}{lr}\text { Layak } & \text { (DPP } \\
\text { lebih } & \text { pendek } \\
\text { dari } & \text { umur } \\
\text { proyek) } & \end{array}$ & \multirow[t]{2}{*}{$\begin{array}{l}\text { (tidak } \\
\text { diketahui) }\end{array}$} & \multirow{2}{*}{$\begin{array}{lr}\text { Karena penda- } & \text { selama } \\
\text { patan } & \text { smur proyek jauh } \\
\text { lebih kecil dari } \\
\text { modal awal. } \\
\begin{array}{l}\text { Sehingga } \\
\text { dikatakan tidak } \\
\text { layak. }\end{array}\end{array}$} \\
\hline & $\begin{array}{lr}\text { Tidal } & \text { Layak } \\
\text { (DPP lebih } \\
\text { panjang dari } \\
\text { umur proyek) }\end{array}$ & & \\
\hline
\end{tabular}

Dari tabel 8. Terlihat bahwa investasi dianggap tidak layak. Kemudian lankah selanjutnya dengan melakukan analisis sensitifitas dengan menaikan harga jual energi ke PLN

Berdasarkan tabel 9. investasi ini layak karena sudah memenuhi ketiga kriteriya kelayakan dari ketiga metode tersebut dengan harga jual energi sebesar Rp 1.932,8. Harga jual energi sebesar $\mathrm{Rp} 1.932,8$ investasi ini jumlahnya masih jauh dengan harga yang sudah ditetapkan sebesar Rp 840,2. Hal ini tentu saja membebankan PLN 
dan Pemerintah karena hanya mensubsidi sebesar Rp1092,6. Tetapi PLN diuntungkan karena tidak mengeluarkan biaya untuk pembangunan PLTS

Tabel 9. Analisis kelayakan investasi PLTS dengan harga jual energi PLN Rp 1932,8/kWh

\begin{tabular}{|c|c|c|c|}
\hline $\begin{array}{l}\text { Analisis } \\
\text { Kelayakan }\end{array}$ & $\begin{array}{l}\text { Kriteria } \\
\text { Kelayakan }\end{array}$ & $\begin{array}{l}\text { Hasil } \\
\text { Analisis } \\
\text { Investasi }\end{array}$ & Kesimpulan \\
\hline Net Present & Layak (NPV > & $\mathrm{Rp}$ & Investasi dianggap layak \\
\hline Value & & 26.029 .762 & diinvestasikan karena \\
\hline (NPV) & $\begin{array}{l}\text { Tidak Layak } \\
(\text { NPV < } 0)\end{array}$ & & $\begin{array}{l}\text { nilai NPV selama umur } \\
\text { proyek lebih besar dari } 0 .\end{array}$ \\
\hline Benefit - & Layak (B-CR > & 1,01 & Investasi dianggap layak \\
\hline Cost Ratio & & & diinvestasikan karena \\
\hline (B-CR) & $\begin{array}{l}\text { Tidak Layak } \\
(B-C R<1)\end{array}$ & & $\begin{array}{l}\text { antara pendapatan dan } \\
\text { investasi bernilai lebih } \\
\text { besar dari } 1 \text {. }\end{array}$ \\
\hline \multirow{7}{*}{$\begin{array}{l}\text { Discounted } \\
\text { Payback } \\
\text { Period } \\
\text { (PP) }\end{array}$} & Layak (DPP & \multirow[t]{7}{*}{24 Tahun } & Dari investasi ini \\
\hline & lebih pendek & & pengembalian modal \\
\hline & $\begin{array}{l}\text { dari umur } \\
\text { proyek) }\end{array}$ & & $\begin{array}{l}\text { terjadi setelah } 24 \text { tahun, } \\
\text { karena pendapatan }\end{array}$ \\
\hline & Tidal Layak & & selama umur proyek jauh \\
\hline & (DPP lebih & & lebih besar dari modal \\
\hline & panjang dari & & awal. Sehingga \\
\hline & umur proyek) & & dikatakan layak. \\
\hline
\end{tabular}

\subsection{Pengolahan Data Biaya Sistem PLTS Simulasi PVSyst}

Tabel 10. Hasil simulasi PVSyst

\begin{tabular}{lcccccc}
\hline & $\begin{array}{c}\text { GlobHor } \\
\text { kWh/m2 }\end{array}$ & $\begin{array}{c}\text { Globlnc } \\
\text { kWh/m2 }\end{array}$ & $\begin{array}{c}\text { EArray } \\
\text { MWh }\end{array}$ & $\begin{array}{c}\text { ELoad } \\
\text { MWh }\end{array}$ & $\begin{array}{c}\text { E User } \\
\text { MWh }\end{array}$ & $\begin{array}{c}\text { E_Grid } \\
\text { MWh }\end{array}$ \\
\hline January & 267.2 & 248.9 & 23.11 & 29.54 & 16.63 & 5.413 \\
February & 230.0 & 221.3 & 20.90 & 25.73 & 14.47 & 5.468 \\
March & 265.9 & 266.8 & 24.98 & 28.30 & 17.23 & 6.686 \\
April & 211.6 & 222.3 & 21.07 & 27.03 & 14.71 & 5.413 \\
May & 232.7 & 254.2 & 23.16 & 29.54 & 16.54 & 5.622 \\
June & 246.5 & 274.7 & 24.09 & 27.03 & 16.37 & 6.729 \\
July & 292.3 & 323.1 & 27.43 & 28.30 & 18.90 & 7.461 \\
August & 312.4 & 333.8 & 28.49 & 29.54 & 20.49 & 6.899 \\
September & 281.1 & 287.1 & 25.89 & 25.80 & 16.75 & 8.115 \\
October & 305.7 & 298.5 & 26.60 & 29.54 & 18.96 & 6.580 \\
November & 213.9 & 203.0 & 19.15 & 28.27 & 13.39 & 4.822 \\
December & 229.2 & 213.1 & 20.12 & 27.07 & 13.23 & 5.900 \\
Year & 3088.5 & 3146.9 & 284.97 & 335.70 & 197.67 & 75.110 \\
\hline
\end{tabular}

Tabel 11. Perhitungan pendapatan energi listrik yang disalurkan ke PLN

\begin{tabular}{lcr}
\hline \multicolumn{1}{c}{ Bulan } & kWh Jual & Pendapatan (Rp) \\
\hline Januari & 5414 & Rp4.548.843 \\
Februari & 5468 & Rp4.594.214 \\
Maret & 6687 & Rp5.618.417 \\
April & 5413 & Rp4.548.003 \\
Mei & 5623 & Rp4.724.445 \\
Juni & 6730 & Rp5.654.546 \\
Juli & 7462 & Rp6.269.572 \\
Agustus & 6899 & Rp5.796.540 \\
September & 8115 & Rp6.818.223 \\
Oktober & 6580 & Rp5.528.516 \\
November & 4822 & Rp4.051.444 \\
Desember & 5900 & Rp4.957.180 \\
\hline Jumlah & 75113 & Rp63.109.943 \\
\hline
\end{tabular}

Tabel 12. Perhitungan penghematan setelah PLTS terpasang

\begin{tabular}{lcccc}
\hline \multicolumn{1}{c}{ Bulan } & E Load & E User & $\begin{array}{c}\text { kWh yang } \\
\text { dihemat }\end{array}$ & $\begin{array}{c}\text { Penghematan } \\
\text { (Rp) }\end{array}$ \\
\hline Januari & 29540 & 16630 & 12910 & Rp9.488.850 \\
Februari & 25730 & 14470 & 11260 & Rp8.276.100 \\
Maret & 28310 & 17230 & 11080 & Rp8.143.800 \\
April & 27040 & 14710 & 12330 & Rp9.062.550 \\
Mei & 29540 & 16540 & 13000 & Rp9.555.000 \\
Juni & 27040 & 16370 & 10670 & Rp7.842.450 \\
Juli & 28310 & 18900 & 9410 & Rp6.916.350 \\
Agustus & 29540 & 20490 & 9050 & Rp6.651.750 \\
September & 25800 & 16750 & 9050 & Rp6.651.750 \\
Oktober & 29540 & 18960 & 10580 & Rp7.776.300 \\
November & 28270 & 13390 & 14880 & Rp10.936.800 \\
Desember & 27070 & 13230 & 13840 & Rp10.172.400 \\
\hline \multicolumn{1}{c}{ Jumlah } & 335730 & 197670 & 138060 & Rp101.474.100 \\
\hline
\end{tabular}

Dari simulasi PVSyst dapat pat diketahui penjualan energi selama setahun sebesar $75113 \mathrm{kWh}$ maka pendapatan dari penjualan energi listrik sebesar Rp63.109.943. penghematan energi listrik setelah terpasang PLTS adalah sebesar $138060 \mathrm{kWh}$ jadi penghematan yang dilakukan selama setahun sebesar Rp101.474.100.

\subsubsection{Analisis Ekonomi Kelayakan Investasi simulasi PVSyst}

Tabel 13. Analisis kelayakan investasi PLTS dengan harga jual energi PLN Rp 840,2/kWh

\begin{tabular}{|c|c|c|c|}
\hline $\begin{array}{l}\text { Analisis } \\
\text { Kelayakan }\end{array}$ & $\begin{array}{c}\text { Kriteria } \\
\text { Kelayakan }\end{array}$ & $\begin{array}{l}\text { Hasil Analisis } \\
\text { Investasi }\end{array}$ & Kesimpulan \\
\hline $\begin{array}{l}\text { Net Present } \\
\text { Value } \\
\text { (NPV) }\end{array}$ & $\begin{array}{l}\text { Layak (NPV > } \\
\text { 0) } \\
\text { Tidak Layak } \\
(\mathrm{NPV}<0)\end{array}$ & $\begin{array}{c}- \\
\text { Rp350.054.527 }\end{array}$ & $\begin{array}{ll}\text { Investasi } & \text { dianggap } \\
\text { tidak layak } \\
\text { diinves-tasikan } \\
\text { karena nilai } & \text { NPV } \\
\text { selama } & \text { umur } \\
\text { proyek lebih } & \text { kecil } \\
\text { dari } 0 . & \end{array}$ \\
\hline $\begin{array}{l}\text { Benefit - Cost } \\
\text { Ratio } \\
\text { (B-CR) }\end{array}$ & $\begin{array}{l}\text { Layak (B-CR > } \\
\text { 1) } \\
\text { Tidak Layak (B- } \\
\text { CR < 1) }\end{array}$ & 0,779 & $\begin{array}{l}\text { Investasi dianggap } \\
\text { tidak layak } \\
\text { diinves-tasikan } \\
\text { karena antara } \\
\text { pendapatan dan } \\
\text { inves-tasi bernilai } \\
\text { lebih kecil dari } 1 .\end{array}$ \\
\hline $\begin{array}{l}\text { Discounted } \\
\text { Payback } \\
\text { Period } \\
\text { (PP) }\end{array}$ & $\begin{array}{l}\text { Layak ( DPP } \\
\text { lebih pendek } \\
\text { dari umur } \\
\text { proyek) } \\
\text { Tidal Layak ( } \\
\text { DPP lebih } \\
\text { panjang dari } \\
\text { umur proyek) }\end{array}$ & $\begin{array}{c}\text { (tidak } \\
\text { diketahui) }\end{array}$ & $\begin{array}{lr}\text { Karena } & \text { DPP } \\
\text { melebihi } & \text { umur } \\
\text { proyek, } & \text { sehingga } \\
\text { dikatakan } & \text { tidak } \\
\text { layak. } & \end{array}$ \\
\hline
\end{tabular}

Kelayakan investasi PLTS yang akan dirancang di Departemen Teknik Elektro Universitas Diponegoro ditentukan berdasarkan hasil perhitungan Net Present Value (NPV), Profitability Index (PI) dan Discounted Payback Period (DPP).

Arus kas bersih tahunan PLTS yang akan dirancang di Departemen Teknik Elektro sebesar Rp148.721.348. Untuk arus kas keluar tahunan PLTS diperhitungkan sebesar Rp15.862.695. Pendapatan yang diperoleh 
selama 25 tahun adalah sebesar Rp1.236.214.973, masih jauh dari biaya investasi yang sebesar Rp1.586.269.500. Dan apabila dihitung menggunakan metode Net Present Value (NPV), Benefit-Cost Ratio (BCR) dan Discounted Payback Period (DPP) maka hasil kelayakan dapat dilihat seberti tabel 13 :

Dari tabel 13. Terlihat bahwa investasi dianggap tidak layak. Kemudian lankah selanjutnya dengan melakukan analisis sensitifitas dengan menaikan harga jual energi ke PLN

Tabel 14. Analisis kelayakan investasi PLTS dengan harga jual energi PLN Rp 1440,2/kWh

\begin{tabular}{|c|c|c|c|}
\hline $\begin{array}{l}\text { Analisis } \\
\text { Kelayakan }\end{array}$ & $\begin{array}{l}\text { Kriteria } \\
\text { Kelayakan }\end{array}$ & $\begin{array}{l}\text { Hasil Analisis } \\
\text { Investasi }\end{array}$ & Kesimpulan \\
\hline $\begin{array}{l}\text { Net Present } \\
\text { Value } \\
\text { (NPV) }\end{array}$ & $\begin{array}{l}\text { Layak (NPV > } \\
\text { 0) } \\
\text { Tidak Layak } \\
(\mathrm{NPV}<0)\end{array}$ & Rp24.562.098 & $\begin{array}{l}\text { Investasi dianggap } \\
\text { layak diinvestasikan } \\
\text { karena nilai NPV } \\
\text { selama umur proyek } \\
\text { lebih besar dari } 0 \text {. }\end{array}$ \\
\hline $\begin{array}{l}\text { Benefit - } \\
\text { Cost Ratio } \\
\text { (B-CR) }\end{array}$ & $\begin{array}{l}\text { Layak (B-CR > } \\
\text { 1) } \\
\text { Tidak Layak (B- } \\
\text { CR < 1) }\end{array}$ & 1,01 & $\begin{array}{lr}\text { Investasi dianggap } \\
\text { layak diinvestasikan } \\
\text { karenar antara } \\
\text { pendapatan dan } \\
\text { investasi bernilai } \\
\text { lebih besar dari } 1 .\end{array}$ \\
\hline $\begin{array}{l}\text { Discounted } \\
\text { Payback } \\
\text { Period } \\
\text { (PP) }\end{array}$ & $\begin{array}{l}\text { Layak ( DPP } \\
\text { lebih pendek } \\
\text { dari umur } \\
\text { proyek) } \\
\text { Tidal Layak ( } \\
\text { DPP lebih } \\
\text { panjang dari } \\
\text { umur proyek) }\end{array}$ & 24 Tahun & $\begin{array}{l}\text { Dari investasi ini } \\
\text { pengembalian modal } \\
\text { terjadi setelah } 24 \\
\text { tahun, karena } \\
\text { pendapatan selama } \\
\text { umur proyek jauh } \\
\text { lebih besar dari } \\
\text { modal } \\
\text { Sehingga dikatakan } \\
\text { layak. }\end{array}$ \\
\hline
\end{tabular}

Berdasarkan tabel 14 investasi ini layak karena sudah memenuhi ketiga kriteriya kelayakan dari ketiga metode tersebut dengan harga jual energi sebesar Rp1.440,2. Harga jual energi sebesar Rp 1.440,2 investasi ini jumlahnya masih jauh dengan harga yang sudah ditetapkan sebesar Rp 840,2. Hal ini tentu saja membebankan PLN dan Pemerintah karena hanya mensubsidi sebesar Rp 600. Tetapi PLN diuntungkan karena tidak mengeluarkan biaya untuk pembangunan PLTS.

\subsection{Perbandingan Analisis Ekonomi HOMER dan Pvsyst}

Tabel 15. Perbandingan hasil analisis investasi HOMER dan Pvsyst kondisi tidak layak

\begin{tabular}{llll}
\hline No. & $\begin{array}{l}\text { Analisis } \\
\text { Kelayakan }\end{array}$ & $\begin{array}{l}\text { Hasil Analisis } \\
\text { Investasi HOMER }\end{array}$ & $\begin{array}{l}\text { Hasil Analisis } \\
\text { Investasi PVsyst }\end{array}$ \\
\hline 1. & $\begin{array}{l}\text { Net Present Value } \\
\text { (NPV) }\end{array}$ & - Rp617.603.068 & - Rp 350.054.527 \\
2. & $\begin{array}{l}\text { Benefit }- \text { Cost } \\
\text { Ratio }\end{array}$ & 0,61 & 0,779 \\
& $\begin{array}{l}\text { (B-CR) } \\
\text { Discounted } \\
\text { Payback Period } \\
\text { 3. }\end{array}$ & (tidak diketahui) & (tidak diketahui) \\
& & \\
\hline
\end{tabular}

Dari tabel 15 terlihat adanya perbedaan hasil analisis investasi HOMER dan PVsyst. Hal ini disebabkan karena hasil simulasi keduanya berbeda. Dari produksi PLTS dengan simulasi HOMER sebesar $255.530 \mathrm{kWh}$ sedangkan PVsyst sebesar $272.800 \mathrm{kWh}$. Dengan produksi PLTS simulasi PVsyst yang lebih besar dari HOMER, maka untuk penjualan energi PVsyst juga lebih besar dari HOMER yaitu PVsyst menjual $75.113 \mathrm{kWh}$ dan untuk HOMER menjual $70.870 \mathrm{kWh}$. Sedangkan pemakian energi listrik setelah ada PLTS dengan HOMER sebesar 158.788 kWh dan Pvsyst sebesar 197.670 kWh

Tabel 16. Perbandingan hasil analisis investasi HOMER dan Pvsyst kondisi layak

\begin{tabular}{llll}
\hline No. & $\begin{array}{l}\text { Analisis } \\
\text { Kelayakan }\end{array}$ & $\begin{array}{l}\text { Hasil Analisis } \\
\text { Investasi HOMER }\end{array}$ & $\begin{array}{l}\text { Hasil Analisis } \\
\text { Investasi PVsyst }\end{array}$ \\
\hline 1. & $\begin{array}{l}\text { Net Present Value } \\
\text { (NPV) }\end{array}$ & Rp26.029.762 & Rp24.562.098 \\
2. & $\begin{array}{l}\text { Benefit }- \text { Cost } \\
\text { Ratio }\end{array}$ & 1,01 & 1,01 \\
& $\begin{array}{l}\text { (B-CR) } \\
\text { Discounted } \\
\text { Payback Period } \\
\text { (PP }\end{array}$ & 24 Tahun & 24 Tahun \\
Harga kWh & Rp 1932,8 & Rp 1.440,2 \\
\hline
\end{tabular}

Untuk mencapai hasil analisis investasi menjadi layak dilakukan dengan menaikkan harga jual energi PLTS. Dari tabel 16 terlihat adanya perbedaan antara harga jual HOMER dan PVsyst untuk mencapai layak. Selain dari produksi PLTS, penjualan energi ke PLN dan pemakaian energi listrik setelah ada PLTS, hal yang mempengaruhi yaitu harga pemeliharaan dan operasional. Dimana untuk HOMER pemeliharaan dan operasional sebesar Rp 73.097.540 yang tercantum pada hasil simulasi. Sedangkan untuk PVsyst sebesar Rp 15.862.695 yang diambil dari 1\% dari investasi awal, karena pada hasil simulasi PVsyst tidak tercantum untuk pemeliharaan dan operasional setiap tahun.

Perbedaan tersebut akan mempengaruhi arus kas bersih yang nantinya juga akan berimbas pada PVNCF dan Comulative PVNCF pada alur kas perencanaan sistem PLTS Departemen Teknik Elektro Universitas Diponegoro. Dengan hasil simulasi HOMER, Comulative PVNCF pada tahun pertama sebesar Rp174.460.976 sedangkan dengan hasil simulasi PVsyst sebesar Rp174.302.165.

\section{Kesimpulan}

Biaya investasi awal yang dikeluarkan untuk perencanaan sistem PLTS di Departemen Teknik Elektro Universitas Diponegoro adalah sebesar Rp1.586.269.500. Berdasarkan hasil simulasi HOMER besar pendapatan selama 25 tahun sebesar Rp 968.666.432. Setelah dilakukan perhitungan analisis ekonomi teknik untuk sistem PLTS yang akan dirancang dinyatakan tidak layak untuk diinvestasikan, karena pendapatan yang didapat dari penjualan energi listrik dengan harga jual energi listrik ke PLN sebesar Rp 
840,2/kWh tidak mampu menutup biaya investasi. Berdasarkan hasil simulasi PVsyst besar pendapatan selama 25 tahun sebesar Rp1.236.214.973. Setelah dilakukan perhitungan analisis ekonomi teknik untuk sistem PLTS yang akan dirancang dinyatakan tidak layak untuk diinvestasikan, karena pendapatan yang didapat dari penjualan energi listrik dengan harga jual energi listrik ke PLN sebesar Rp 840,2/kWh tidak mampu menutup biaya investasi. Analisis sensitivtas hasil simulasi HOMER dapat dikatakan layak apabila harga jual energi listrik ke PLN sebesar Rp 1932,8/kWh karena pendapatan selama 25 tahun sebesar Rp 1.612.299.262 sudah mampu menutup biaya investasi. Analisis sensitivtas hasil simulasi PVsyst dapat dikatakan layak apabila harga jual energi listrik ke PLN sebesar Rp 1440,2/kWh karena pendapatan selama 25 tahun sebesar Rp 1.610.831.598 sudah mampu menutup biaya investasi. Dari kekurangan yang ada, penulis memiliki beberapa saran demi hasil yang lebih baik nantinya, berikut saran yang dapat dipertimbangkan jika ada yang berminat untuk melanjutkan atau mengembangkan Penelitian ini. Analisis ekonomi PLTS dapat dikembangkan dengan memperhitungkan biaya penggunaan kabel dan pemasangan kabel. Analisis ekonomi PLTS dapat dikembangkan dengan memperhitungkan biaya pembangunan ruang komponen. Perlu dikembangkan mengenai dampak pengurangan gas penyebab emisi, seperti $\mathrm{CH} 4$ dan $\mathrm{N} 2 \mathrm{O}$ dari penggunaan teknologi photovoltaic sebagai pengganti pembangkit pembangkit konvensional.

\section{Referensi}

[1]. I. Fitriana, OUTLOOK ENERGI INDONESIA 2017. BADAN PENGKAJIAN DAN PENERAPAN TEKNOLOGI, 2017.
[2]. P. H. J, “ANALISIS KEEKONOMIAN KOMPLEKS PERUMAHAN BERBASIS ENERGI SEL SURYA (STUDI KASUS: PERUMAHAN CYBER ORCHID TOWN HOUSES, DEPOK)," FT UI, 2012.

[3]. A. M. Thyra, M. Facta, and Karnoto, "ANALISIS EKONOMI PENGGUNAAN INVERTER SEL SURYA PELANGGAN RUMAH TANGGA TERHUBUNG DENGAN JARINGAN PADA PERUMAHAN SYAILENDRA RESIDENCE BANYUMANIK SEMARANG," pp. 1-15, 2015.

[4]. Yakin and E. A. Z, "PERENCANAAN PEMBANGKIT LISTRIK HYBRID DI PULAU GILI LABAK KABUPATEN SUMENEP MADURA MENGGUNAKAN TEKNIK DISTRIBUTED GENERATION," Semin. Nas. Sains dan Teknol. Terap. IV, pp. 265-272, 2016.

[5]. Kunaifi, "DESAIN PEMBANGKIT LISTRIK HYBRID ( PLTS-DIESEL ) UNTUK MENINGKATKAN PELAYANAN KESEHATAN DI PUSKESMAS KECAMATAN GEMA KABUPATEN KAMPAR," J. Sains, Teknol. dan Ind., vol. 10, no. January, pp. 15-21, 2011.

[6]. A. E. A. Nafeh, "Design and Economic Analysis of a Stand-Alone PV System to Electrify a Remote Area Household in Egypt," Open Renew. Energy J., vol. 2, pp. 33-37, 2009.

[7]. Moh. Ega Elman Miska, SP, MSi, "Studi Kelayakan Bisnis Pembayaran Pinjaman," Gunadarma. Univ., 2016.

[8]. M. E. D. S. D. M. R. INDONESIA, "PERATURAN MENTERI ENERGI DAN SUMBER DAYA MINERAL REPUBLIK INDONESIA NOMOR 50 TAHUN 2017 TENTANG PEMANFAATAN SUMBER ENERGI TERBARUKAN UNTUK PENYEDIAAN TENAGA LISTRIK," 2017.

[9]. D. G. Newnan, T. G. Eschenbach, and J. P.Lavelle, ENGINEERING ECONOMIC ANALYSIS. 2004.

[10]. Hj. Salmah Said, "Manajemen Keuangan I," Universitas islam Negeri Alauddin makasar., 2013. 